\title{
Complementary and integrative therapies in the scope of nursing: legal aspects and academic-assistance panorama
}

\author{
Práticas integrativas e complementares no âmbito da enfermagem: aspectos legais e panorama \\ acadêmico-assistencial
}

\section{Prácticas integradoras y complementarias en el ámbito de la enfermería: aspectos legales y panorama académico-asistencial}

\author{
Cissa Azevedo ${ }^{1}(\mathbb{C}$ \\ Caroline de Castro Moura ${ }^{1}$ (D) \\ Hérica Pinheiro Corrêa ${ }^{2}$ (C) \\ Luciana Regina Ferreira da Mata ${ }^{1}$ (ic) \\ Érika de Cássia Lopes Chaves ${ }^{3}$ (i] \\ Tânia Couto Machado Chianca ${ }^{1}$ (C)
}

1. Universidade Federal de Minas Gerais. Escola de Enfermagem. Belo Horizonte, MG, Brasil

2. Hospital Sofia Feldman. Belo Horizonte, MG, Brasil

3. Universidade Federal de Alfenas. Alfenas, MG, Brasil

\begin{abstract}
Objective: to carry out a documentary study on the legal aspects that support the nurses' performance in the Integrative and Complementary Practices (PIC) and to discuss the panorama of teaching, research, extension and nursing activities in front of PICs. Method: documentary study, whose units of analysis were normative, guidelines, recommendations and clarification notes $(n=17)$. The data were organized into two categories: "Legal aspects of nurses' performance in ICP and acupuncture" and "Overview of the use of ICPs by nursing in the areas of teaching, research, extension and assistance activities". Results: nurses stand out in the implementation of PIC since the principles of training are congruent to the paradigms of this science, besides having legal support for acting in public and private services in Brazil. There is an incipient movement of nurses working in research and extension in universities, which contributes to the diffusion of knowledge and application of therapies in the community. Conclusion: the institutionalization of PICs in the Unified Health System has increased access and contributed to the provision of comprehensive and multidisciplinary health services. Implications for practice: with ICPs, nurses have achieved autonomy and the possibility of expanding their performance, aiming at a better quality of care.
\end{abstract}

Keywords: Nursing Care; Comprehensive Health Care; Complementary Therapies; Acupucture Therapy.

\section{RESUMO}

Objetivo: Realizar estudo documental sobre os aspectos legais que respaldam a atuação do enfermeiro nas Práticas Integrativas e Complementares (PIC) e discorrer sobre o panorama do ensino, pesquisa, atividades extensionistas e assistenciais da Enfermagem frente às PIC. Método: Estudo documental, cujas unidades de análise foram normativas, diretrizes, recomendações e notas de esclarecimento $(n=17)$. Os dados foram organizados em duas categorias: "Aspectos legais da atuação do Enfermeiro nas PIC e na acupuntura" "Panorama da utilização das PIC pela enfermagem nas áreas de ensino, pesquisa, atividades extensionistas e assistenciais". Resultados: Os enfermeiros se destacam na implementação das PIC uma vez que os princípios de formação são congruentes aos paradigmas dessa ciência, além de possuírem respaldo legal para atuação em serviços públicos e privados no Brasil. Há um movimento incipiente de enfermeiros atuando em pesquisas e extensão nas universidades, o que contribui para difusão do conhecimento e aplicação das terapias na comunidade. Conclusão: A institucionalização das PIC no Sistema Único de Saúde ampliou o acesso e tem contribuído para disponibilização de serviços de saúde integral e multidisciplinares. Implicações para prática: Com as PIC os enfermeiros têm alcançado autonomia e possibilidade de expansão de sua atuação, com vistas à melhor qualidade do cuidado.

Palavras-chave: Cuidados de Enfermagem; Assistência Integral à Saúde; Terapias Complementares; Terapia por Acupuntura.

\section{REsumen}

Objetivo: realizar un estudio documental sobre los aspectos legales que respaldan la actuación del enfermero en las Prácticas Integradoras y Complementarias (PIC) y discurrir sobre el panorama de la enseñanza, investigación, las actividades extensionistas y asistenciales de la Enfermería frente a las PIC. Método: estudio documental, cuyas unidades de análisis fueron normativas, directrices, recomendaciones y notas de aclaración $(n=17)$. Se organizaron los datos en dos categorías: "Aspectos legales de la actuación del Enfermero en las PIC y en la acupuntura" y "Panorama de la utilización de las PIC por la enfermería en las áreas de enseñanza, investigación, actividades extensionistas y asistenciales". Resultados: los enfermeros se destacan en la implementación de las PIC, ya que los principios de formación son congruentes a los paradigmas de esta ciencia, además de poseer respaldo legal para actuación en servicios públicos y privados en Brasil. Hay un movimiento incipiente de enfermeros actuando en investigaciones y extensión en las universidades, lo que contribuye a la difusión del conocimiento e implementación de terapias en la comunidad. Conclusión: la institucionalización de las PIC en el Sistema Único de Salud amplió el acceso y contribuye a una disponibilidad de servicios de salud integral y multidisciplinar. Implicaciones para la práctica: con las PIC los enfermeros han alcanzado autonomía y la posibilidad de expandir su actuación, con vistas a una mejor calidad del cuidado.

Palabras clave: Atención de Enfermería; Atención Integral de Salud; Terapias Complementarias; Terapia por Acupuntura. 


\section{INTRODUCTION}

The World Health Organization (WHO) designates "Traditional and Complementary Medicine" a broad set of care practices, knowledge and therapeutic products that do not belong to conventional or allopathic medicine. ${ }^{1}$ Such practices can be divided into two major groups: 1- Medical ratios (naturopathy, homeopathy, Ayurveda, Traditional Chinese, Anthroposophical and Tibetan Medicine), and 2 Therapeutic Practices, which include $\mathrm{mind} / \mathrm{body}$ interventions, body manipulation therapies, natural and energetic therapies. ${ }^{2}$

Professionals/therapists are encouraged to establish an expanded vision of the health-disease process and the integral promotion of human care, especially self-care. ${ }^{3}$ This is the incentive to a new paradigm in health called Vital Paradigm, whose focus is on health and the search for balance of the individual with their natural and social environment, valuing the singularities of care, prevention and health promotion. ${ }^{4}$

Traditional and Complementary Medicine is contemplated by the Unified Health System (SUS) since the 1980s, mainly because of the report of the Eighth National Health Conference in 1986, which supported the insertion of complementary practices into care ${ }^{1}$. However, its expansion in SUS occurred through Ordinance 971 of 2006, which established the National Policy on Integrative and Complementary Practices (PNPIC). ${ }^{3}$ Besides this ordinance legitimizing the public offering of different therapies, it also enabled non-medical professionals to practice complementary medicine through accreditation and remuneration by the SUS. ${ }^{1}$

In this context, nursing, being a science of a humanistic nature, can find in these practices new ways to better serve its clientele, with emphasis on health promotion and disease prevention. $^{2}$

Specifically in the context of nursing, the principles that govern Integrative and Complementary Practices (PIC) are congruent to those of this science. Nursing care and the PICs assume that their actions are focused on the human being and their interrelations with the natural environment, not on the pathology itself. Therefore, these sciences have holistic tendencies, since they follow the perspective of attention to the individual as a whole; and the process of becoming ill is associated with possible external and internal imbalances that affect energy, the individual, health and physical space, as well as the interrelationships between them. ${ }^{5}$

Thus, in view of the growing incentive to expand the offer of PICs in the SUS, with its implementation in the multiprofessional sphere and considering the need to discuss the Nursing and PIC interface, this article aimed to conduct a documentary study on the legal aspects that support the role of nurses in Integrative and Complementary Practices (PIC) and to discuss the panorama of teaching, research, extension (academic) and Nursing care activities in relation to PICs.

\section{METHOD}

It is a documentary study, whose units of analysis were normative, guidelines, recommendations and clarification notes that deal with the PIC interface and nursing. Official documents of national and international public bodies dealing with the subject were also consulted.

The documents were collected between September 2018 and February 2019, in the database Virtual Health Library - Traditional, Complementary and Integrative Medicines (BVS-MTCl), tab "Regulations and Policies in MTCl", in addition to searches in official sites of the nursing disciplinary body http://www.cofen. gov.br/), Ministry of Health (http://portalms.saude.gov.br/) and WHO (https://www.who.int/medicines/publications).

The publications were selected by quality criteria that considered authenticity (primary document), credibility (documents with no errors or distortions), representative (typical of the institution) and meaning (clear and understandable). ${ }^{6}$ In addition, a convenience sample was adopted, seeking the intertextuality between the national and international scope that could point out the different connections or confluent institutional positions about the regularization of PIC exercise by nurses in health care services.

For analysis, a pre-exploration phase of the corpus floating material or readings and from previous knowledge, clinical experience on the topic addressed and the points discussed in the studies and selected documents, information was organized for discussion in two categories: "Legal aspects of nurses' performance in PIC and acupuncture" and "Overview of the use of PICs by nursing in teaching and research areas, in extension and assistance activities".

As it was a research with data of access and public domain, the submission to the Ethics Committee in Research was dispensed with.

\section{RESULTS AND DISCUSSION}

\section{Legal aspects of nurses' performance in PIC and acupuncture}

Seventeen documents were analyzed, including five ministerial ordinances, five resolutions of the Federal Nursing Council (COFEN), five general documents (reports, recommendations and clarification notes) and two international documents. They were categorized in Table 1, considering the type of document, date and locator.

The fact of the PNPIC establishes the insertion of PICs into Primary Health Care (APS), which is considered the gateway to the health care network, contributes to the expansion of access to them, and to continued, resolute, humanized and integral care. However, the institution of PICs in the SUS is considered a challenge for public managers, mainly due to insufficient funding, scarcity of spaces for the implementation of new therapies 
Table 1. Documents that support the performance of Nursing in the framework of Integrative and Complementary Practices $(2006-2019)(n=17)$.

№ Document
1 Ministry of Health. Ordinance No. 971, dated May 3, 2006. Approves the PNPIC in
SUS.
Ministry of Health. Ordinance No. 853, dated Friday, November 17, 2006. Include
in the Table of Services/classifications of the System of National Register of He-
alth Information Establishments of SUS, the service code 068 - PIC composing it
with the following classifications.
COFEN. Resolution 197/1997. Establishes and recognizes Alternative Therapies as
a specialty and/or qualification of the Nursing professional.

4 COFEN. Resolution 362/2008. Regulates in the COFEN/CORENs System the activity of acupuncture and disposes about the registration of the specialty.

$5 \quad$ Ministry of Health. CNS. Recommendation No. 027, dated October 15, 2009.

6

Ministry of Health. Basic Attention Reports No. 53. PIC in SUS: expansion of access.

7 Ministry of Health. CNS. Recommendation No. 010, dated August 11, 2011.

9

World Health Organization. Traditional medicine strategy: 2014-2023.

COFEN. Resolution 0500/2015. It expressly revokes COFEN Resolution 197, dated

10 March 19, 1997, which provides for the establishment and recognition of Alternative Therapies as a specialty and/or qualification of the Nursing professional, and makes other provisions.

Ministry of Health. Ordinance No. 145, dated Wednesday, January 11, 2017.

11 Changes procedures in the Table of Procedures, Medications, Orthotics, Prostheses and Special Materials of SUS for assistance in Primary Care.

Ministry of Health. Ordinance No. 849, dated Monday, March 27, 2017. It includes Art Therapy, Ayurveda, Biodanza, Circular Dance, Meditation, Music Therapy, Naturopathy, Osteopathy, Chiropractic, Reflexotherapy, Reiki, Shantala, Integrative Community Therapy and Yoga to PNPIC.

Ministry of Health. Ordinance No. 702, dated March 21, 2018. Changes Conso- http://bvsms.saude.gov.br/

bvs/saudelegis/gm/2006/ prt0971_03_05_2006.html

http://189.28.128.100/

dab/docs/legislacao/porta-

ria853_17_11_06.pdf

http://www.cofen.gov.br/ resoluo-cofen-1971997_4253. html

http://www.cofen.gov. $\mathrm{br} /$ resoluao-cofen-n-3262008_5414.html

http://conselho.saude.gov.br/ ultimas_noticias/2012/19_

abr_recomendacao_acupuntura.html

http://189.28.128.100/dab/ docs/publicacoes/informes/ psfinfo53.pdf

http://conselho.saude.gov.br/ ultimas_noticias/2012/19_ abr_recomendacao_acupuntura.html

http://conselho.saude.gov.br/ ultimas_noticias/2012/19_

abr_recomendacao_acupuntura.html

https://www.who.int/medicines/publications/traditional/ trm_strategy14_23/en/

http://www.cofen.gov. $\mathrm{br} /$ resolucao-cofen-no-05002015_36848.html

http://bvsms.saude.gov.br/ bvs/saudelegis/sas/2017/ prt0145_11_01_2017.html

http://bvsms.saude.gov.br/ bvs/saudelegis/gm/2017/ prt0849_28_03_2017.html

http://bvsms.saude.gov.br/ bvs/saudelegis/gm/2018/ prt0702_22_03_2018.html 


\begin{tabular}{|c|c|c|}
\hline № & Document & Finder \\
\hline 14 & $\begin{array}{l}\text { COFEN. Resolution } 581 / 2018 \text {. Updates, within the scope of the COFEN/CORENs } \\
\text { System, the procedures for Registration of Postgraduate Degrees Lato and Strictu } \\
\text { Sensu granted to Nurses and approves the list of specialties. }\end{array}$ & $\begin{array}{l}\text { http://www.cofen.gov. } \\
\text { br/resolucao-cofen- } \\
\text {-no-581-2018_64383.html }\end{array}$ \\
\hline 15 & $\begin{array}{l}\text { Note of clarification to the Department of Basic Attention of the Ministry of Heal- } \\
\text { th. Embassy of the People's Republic of China. Note } n^{\circ} 155 / 2018 \text {. }\end{array}$ & $\begin{array}{l}\text { https://www.coffito.gov.br/ } \\
\text { nsite/wp-content/uploa- } \\
\text { ds/2018/08/nota_embaixa- } \\
\text { da_china.pdf }\end{array}$ \\
\hline 16 & $\begin{array}{l}\text { COFEN. Resolution 585/2018. Establishes and recognizes acupuncture as a spe- } \\
\text { cialty and/or qualification of the nursing professional. }\end{array}$ & $\begin{array}{l}\text { http://www.cofen.gov. } \\
\text { br/resolucao-cofen- } \\
\text {-no-585-2018_64784.html }\end{array}$ \\
\hline 17 & $\begin{array}{c}\text { Declaration of Parents of } 2018 \text { that recognizes acupuncture as intangible heritage } \\
\text { of humanity. }\end{array}$ & https://www.wad-o.com/en/ \\
\hline
\end{tabular}

Note: PNPIC: National Policy on Integration and Complementary Practices; SUS: Unified Health System; PIC: Integration and Complementary Practices; COFEN - Federal Nursing Council; COREN: Regional Nursing Council; CNS: National Health Council.

and also to the difficulty of connecting the PICs and the healing model. ${ }^{7}$ Another important challenge refers to the few trained human resources, and authors show that the assistance offered by PIC professionals is still insufficient in relation to high demand, which requires expansion and operational planning. ${ }^{8}$

The PNPIC guidelines and actions, recently reformulated and extended by resolutions 145 and 849 of 2017 and 702 of 2018, are underpinned by national policies, such as Basic Care $(A B)$, health promotion and humanization. ${ }^{9}$ Such associations are recommended by the Ministry of Health as a tactic of expansion and integration of PICs at different levels of health care, with a view to new therapeutic options for SUS users, with multiprofessional character. ${ }^{9-13}$

The WHO strategy on traditional medicine 2014-2023 aims to assist health authorities in identifying solutions that enhance the aspects associated with improving the health and independence of patients. The strategy has two main objectives: to provide support to Member States to make use of the potential contribution of MTC to health, and to promote the effectiveand safe use of MTC by means of product, practice and professional regulation. In this document it is established that PICs can be applied by MTC-trained therapists and health professionals such as physicians, dentists, nurses, pharmacists, physiotherapists and physical educators, provided they have specific training. ${ }^{14}$ It should be understood that this document was published after the PNPIC, so an update of the national policy guidelines on PIC may be necessary. ${ }^{15}$

In 2011, the plenary of the National Health Council (CNS), together with the Pan American Health Organization (PAHO), established in Brazil a collaborating center and disseminator of PICs. In addition, he recommended that MS encourage the creation of Multiprofessional Residences in the area and issued a letter to the National Health Agency (ANS) so that acupuncture operators and other PICs accredit their network multiprofessional. ${ }^{16}$

Today, acupuncture is considered one of the most well-known PICs in the world. In fact, diffusion of PICs was initiated by acupuncture; and the acceptability of this therapy is increasing, so that $80 \%$ of WHO's 129 member countries recognize it as a therapeutic intervention. ${ }^{14}$

At the national level, in the year 2016, registered more than two million PIC care in the Basic Health Units of the SUS, and more than 770 thousand were from Traditional Chinese Medicine/ Acupuncture. ${ }^{17}$ Also, a recent literature review, which aimed at analyzing the implementation, access and use of PICs in the SUS, indicated that $90 \%$ of the included studies approached this therapy. ${ }^{10}$

Created over 2,500 years ago in China, acupuncture is one of the oldest treatments in the world. Back in 1985, the country's health system acknowledged the therapeutic relevance for primary health care in the prevention and promotion of health. ${ }^{18}$

In 2003, in order to ensure greater recognition and rationale for acupuncture, the WHO conducted a worldwide consultation on controlled clinical trials using the technique in different diseases, and organized a review of the clinical trials conducted over the past two decades. The results pointed out a list of 43 acute and chronic diseases that are treatable by acupuncture, such as acute, chronic or oncological pain, disorders of the respiratory, digestive and nervous systems, psychological and emotional problems; ${ }^{18}$ in addition, it highlighted its use for all age groups, and at all levels of health care, with a high degree of resolution and efficiency. ${ }^{19}$

In Brazil, in 1988, through Resolutions 4, 5, 6, 7 and 8/1988 of the Interministerial Planning and Coordination Commission (CIPLAN), acupuncture had its standards set for care in public health services. ${ }^{20}$ And in 1999, the MS inserted, in the table of the Outpatient Information System of SUS, the medical consultation in acupuncture. ${ }^{20}$ Class councils of the different health professions then began to recognize acupuncture as a specialty, and among them, the nursing profession. ${ }^{21}$ From 2006, with the approval of the PNPIC, by MS, acupuncture was instituted as a multiprofessional activity. ${ }^{3}$

With the dissemination of the PNPIC and WHO's constant encouragement of the dissemination of PICs as a multidisci- 
plinary activity, several non-SUS health organizations began to accept acupuncture as a practice of several health professions. An example is Ordinance NR 07/DGP of 2007, which approved the exercise of acupuncture in the field of health services of the army, recognizing it, also, as a multidisciplinary practice. ${ }^{21}$

Specifically in nursing, acupuncture can be considered a care technology to be applied to the set of therapeutic interventions of the nurses, in their diverse fields of action..$^{21}$ This recognition began in 2008, when COFEN regulated acupuncture activity and considered it to be a specialty of the nurse. ${ }^{22}$

Currently, Holistic and Complementary Therapies are reaffirmed as a Nursing specialty through COFEN Resolution 581 of 2018, assuring the safety and support of this professional to perform in this scenario, as well as to develop research in the area of PICs in general. ${ }^{23}$

In 2009, the CNS advised the ANS that health care providers offering acupuncture services should include within their credentialed professional staff, all those with a specialty in acupuncture, including nurses. ${ }^{24}$ Also in 2012, it warned managers and health service providers to look at the multiprofessional nature of PICs at all levels of the health care network, as well as in the implementation of health policies or programs related thereto; and the state and municipal health councils to take timely steps to comply with national policy in order to publicize the multiprofessional character of acupuncture and expand its access. ${ }^{25}$

However, there is still a strong restriction of health insurance plans in registering non-medical acupuncturists. In addition, some municipalities, within SUS scope, also restrict such vacancies only for this class, despite the whole support of acupuncture as a multiprofessional practice.

There is also strong medical-class corporatism around the practice of acupuncture in Brazil. In 2001, the Federal Council of Medicine (CFM) filed suit against COFEN to rescind Resolution № $197 / 97,{ }^{26}$ which established and recognized alternative therapies as a specialty or qualification of the nursing professional, stating that acupuncture would be a private activity for physicians. According to the arguments presented by the Medical College of Acupuncture, the nursing professionals were not qualified to carry out clinical diagnoses and prescription of treatment.

The judgment upheld the request of CFM, so that, in 2015, a lawsuit issued by the Judge of the 14th Federal Court of the Judicial Section of the Federal District prevented the registration of acupuncture titles. COFEN then revoked the resolution 197/1997 by means of resolution $500 / 2015 ;{ }^{27}$ but appealed to the lawsuit.

Amid this scenario about the legality or otherwise of the practice of acupuncture by non-medical professionals, COFEN approved, through Resolution 581/2018, the list of specialties by area of coverage. In this resolution, acupuncture was framed within the subarea Nursing in Integrative and Complementary Practices, which composes area I - Collective Health; Child and adolescent health; and Adult Health; ${ }^{23}$ that is, COFEN remained in the fight to regulate the exercise of acupuncture by the specialist nurse.

In that same year, the Embassy of the People's Republic of China in Brazil issued a clarification note to the Department of Basic Health of the MS that Traditional Chinese Medicine has its own theoretical system, which is independent of allopathic medicine; thus, to practice acupuncture it is not necessary to be trained in Western medicine. ${ }^{28}$

COFEN soon won a lawsuit, assuring the practice of acupuncture by specialist nurses, and launched the resolution $585 / 2018$, which establishes and recognizes acupuncture as a specialty and/or qualification of the nursing professional, ${ }^{29}$ in order to further support the nurse in the exercise of this activity.

More recently, WHO, together with the World Federation of Acupuncture-Moxibustion Societies and the United Nations Educational, Scientific and Cultural Organization (UNESCO), which recognizes acupuncture as intangible cultural heritage of mankind, issued the Paris Declaration of 2018, establishing November 15 as the world day of acupuncture. This document aims to promote the internationalization of education in acupuncture and moxibustion through cultural integration; promote the acupuncture and moxibustion legislation in all countries in order to ensure a safe, effective and accessible service; attach importance to the preservation and innovative development of such practices; foster the transdisciplinary development of acupuncture; and to improve the capacity and level of quality of these therapies in the prevention and cure of diseases and in the preservation of health. ${ }^{30}$

Regarding the transdisciplinary/multidisciplinary character of acupuncture, it is emphasized that it is based on the establishment of energetic diagnoses, which are not related to nosological diagnoses. Yet, acupuncture does not belong to any professional category, being a free practice for all who are qualified; in addition, the professional councils have the power to legislate only on their professions, so that no council should interfere with the advice of another professional category. Finally, in Brazil there is no federal legislation that prohibits the practice of acupuncture for non-medical professionals; consequently, the practice of this therapy by health professionals is allowed, and this is guaranteed by constitutional principles, according to item II, of article 5 of the Federal Constitution. ${ }^{31}$

Nursing, through its diagnoses, seeks individual, family or community responses to actual or potential health problems/life processes in order to list interventions aiming at the achievement of results for which nurses are responsible. In this context, acupuncture, which can be considered as a curative and rehabilitative intervention for several diseases, due to the holistic principles underlying it, may be capable of totally or completely solving several of these diagnoses, such as acute pain, chronic pain, nausea, stress urinary incontinence, constipation, insomnia, fatigue, anxiety, obesity, unbalanced energy field, among others. ${ }^{32}$ 
Moreover, just like nursing, acupuncture has a unique contribution to disease prevention, since one of its objectives is to restore energy disorders, which precede their manifestations. ${ }^{19}$

Therefore, acupuncture is an intervention for nursing care capable of serving the man in a more comprehensive and less medicalized perspective that can be applied in its various fields of action and at all levels of health care. ${ }^{5}$

\section{Overview of the use of PICs by nursing in the areas of teaching, research, extension and assistance activities}

The training of nurses is based on Law No. 4998, of 1986 , which regulates Nursing practice regulations and Nursing Professionals Code of Ethics, which was updated by Resolution 564 of 2017 , both of COFEN. ${ }^{33}$ In addition, it is based on the National Curriculum Guidelines established by the Ministry of Education. ${ }^{34}$ From these documents, nursing education institutions construct the Pedagogical Political Projects (PPP), which are strongly influenced by the current care model.

After the implementation of the SUS and changes in health care paradigms, the training of general nurses was centered on the holistic model, with the aim of developing critical and reflexive skills in this professional, which respond to the health demands of the population. Although this proposal exists, there are still gaps in the curricular curricula of nursing courses in relation to new demands, such as PICs, which had already proposed regularization in SUS since the Eighth National Health Conference. ${ }^{35}$

The first records of the inclusion of disciplines about PICs date back to the 90 s with the discipline "Alternative Therapeutic Methods", at the Federal University of Santa Catarina, where practices such as inner healing and hand laying, parapsychology, massage therapy, anthroposophy, Tui-na, acupuncture, yoga, geotherapy and herbal medicine. Although at the time the discipline was well accepted by the student body, the implantation found resistance from a group of teachers. ${ }^{36}$ Nowadays, besides these difficulties, the reduction of the hours of the nursing curriculum weakens the implantation of these disciplines. ${ }^{35}$

Of the 87 Brazilian public institutions, only $23(26.1 \%)$ offer courses related to PICs, of which only six $(26.1 \%)$ are compulsory ${ }^{35}$ These data confirm the shortcomings in undergraduate education and the disagreement of curricula with PNPIC, which foresees in its guidelines the extension of the formal insertion of Traditional Chinese Medicine/acupuncture and other practices in undergraduate and postgraduate courses for the health professions. ${ }^{3}$

Since most of the nurses' contact with PICs occurs only in specialization and qualification courses, the knowledge about the therapies is insufficient and the professionals are unable to indicate or describe them to the users. ${ }^{37}$ Because of poor knowledge, skepticism about PICs in academic settings makes it difficult to implement. ${ }^{38}$

As for the research in the framework of PIC, it is perceived that it requires a scientific plurality that validates modes of knowledge based on qualitative research, including the individual's perception, in order to subsidize the understanding about the therapist-patient relationship and the repercussion of this in the desired results. ${ }^{4}$ On the other hand, research with quantitative approaches may also provide theoretical rationale and ensure the safety of practices for individuals.

In an informal search conducted in the Directory of Research Groups in Brazil, using the term "Integration and Complementary Practices", 14 groups/nuclei were identified, whose names included this term, and of these eight (57.1\%), are from the Collective Health area, four (28.5\%) from Nursing, and the other (14.3\%) from Agronomy and Biophysics. It should be stressed that research groups, by allowing the union of the universes: teaching, research and extension, favor students' understanding of the practical application of knowledge, whether to practice their chosen profession with scientific rigor or to become a researcher.

An important advance for research, given the lack of data in PIC, was the creation of the Virtual Health Library (BVS) in Traditional, Complementary and Integrative Medicines in the BVS portal, which includes approximately 2,556,569 titles on the most practice. In addition, certain PICs, such as acupuncture and homeopathy, have more studies with a strong level of evidence when compared to other practices. ${ }^{10}$

In addition to the academic walls, PICs appear in extension projects and professional experience, as a possibility to balance science and tradition. Extension projects are relevant as they provide scientific input from teaching and research to community movements that are responsible for processes of social, environmental, and political change. In addition, the critical reflection on the practice and the exchange of knowledge consolidates the realization of safe and culturally accepted practices.

Although the mapping of extension actions about PICs in Brazil does not exist, it is well known that educational institutions, especially public ones, have invested in the theme. Among them, the federal universities of Minas Gerais, Goiás, São Paulo and Alfenas and the state of São Paulo collaborate to offer practices and disseminate knowledge among students, teachers and society and are conducted by nurses.

In relation to labor activities with PICs, the profile of professionals in Brazil is unknown. Against this, the MS has sought to identify professionals, groups and research in progress, in order to assess the amount of manpower available to the population. However, it is already known that with the institutionalization of practices by PNPIC, access has been extended and is no longer restricted to private area. ${ }^{39}$

In SUS, most PICs have been offered in Primary Health Care, followed by secondary care. ${ }^{8}$ In tertiary care, where practices are predominantly biomedical, PICs do not yet have significant space and repercussions. ${ }^{1}$ The conditions of the workplace are still cited as the main difficulties for nurses. ${ }^{40}$ However, the interest and acceptance of the users and the favorable climate with the team have contributed to the implementation of PICs in different scenarios.

The practice of PICs by nurses and their remuneration in the SUS includes acupuncture, other MTC techniques, corporal 
practices, physical activity and anthroposophical medicine by Ordinance No. 853, of 17 of 2006, which includes, in the Services Table/classifications of the System of National Registry of Health Establishments (SCNES), the PICs described. ${ }^{40}$ Although practices such as phytotherapy, thermal therapy and crena therapy are not described in the table, they can also be developed by nurses within SUS and the private sector.

However, nurses still represent a small proportion of professionals who use PICs in their practice. The analysis of data from the SUS Ambulatory System (SIA-SUS) reveals that in 2015, of the 928,436 acupuncture procedures performed, $45 \%$ were physicians, $40 \%$ were physiotherapists, $6 \%$ were psychologists and $4 \%$ were nurses. ${ }^{17}$ This demonstrates that, even with the increase in the number of health professionals after the implementation of the policy, the nurses did not present advances in relation to the number of procedures, or they failed to record care and implementation of PICs in their work routines.

However, the relevance of nurses in the diffusion of knowledge related to PICs and their participation in research and extension projects is evidenced. Although there are weaknesses in the training and performance of nurses, these professionals present theoretical foundations congruent with PICs, and therefore, when exposed to them, they have so much affinity. Thus, nursing schools and professionals should seek to find out about these different therapeutic tools, which as a nursing intervention, also considers the individual in its entirety. It is reiterated that the techniques, in addition to being used in SUS work, can be offered as services, opening a range of performance and professional autonomy.

\section{FINAL CONSIDERATIONS}

Considering the above, it can be seen that PICs play an important role in people's health, since they act in the mechanisms of health promotion, disease prevention and rehabilitation. Its institutionalization in SUS expanded access to services previously restricted to the private area, in addition to contributing to the development of humanized, comprehensive and multidisciplinary services, in line with SUS principles, however, much more needs to be done.

Nurses are prominent professionals in the implementation and use of PICs, since the principles of their training are congruent to the paradigms of this science. In addition, they have legal support for acting in public and private services. However, there is still a small contingent of those professionals who act with these therapies or have the knowledge to prescribe and refer users to this type of service. This may be due to gaps during vocational training, since subjects related to PICs are almost not addressed during graduation. However, there is a movement, albeit slow, of nurses working in research and extension activities within universities and in clinical practice in basic health units and private institutions; this contributes to the dissemination of scientifically based knowledge and to the dissemination of these therapies to the community.
It is important to understand that with the advent of PICs, new opportunities begin to emerge for nursing, with a view to autonomy, through an efficient therapeutic action that considers the biopsychosocial complexity of the individual receiving the care. Thus, it is suggested that nurses should recognize the new opportunity that expands for the profession, moving towards the improvement of nursing care.

Therefore, a long way still needs to be addressed in order to strengthen the use of PICs in SUS and by nurses, who may find in these therapies a possibility of intervention for the benefit of society.

\section{FINANCIAL SUPPORT}

Foundation for Research Support of the State of Minas Gerais (FAPEMIG) (APQ-01681-18 and APQ - 03583-18), National Council of Scientific and Technological Development (CNPq) Call MCTIC/CNPq No. 28/2018 (Process number 429958/2018-8)

\section{REFERENCES}

1. Souza IMA, Tesser CD. Medicina Tradicional e Complementar no Brasil: inserção no Sistema Único de Saúde e integração com a atenção primária. Cad Saúde Pública [Internet]. 2017; [cited 2018 Dec 21]; 33(1):e00150215. Available from: http://www.scielo.br/pdf/csp/ v33n1/1678-4464-csp-33-01-e00150215.pdf

2. Balouchi A, Mahmoudirad G, Hastings-Tolsma M, Shorofi SA Shahdadi $\mathrm{H}$, Abdollahimohammad A. Knowledge, attitude and use of complementary and alternative medicine among nurses: A systematic review. Complement Ther Clin Pract [Internet]. 2018 May; [cited 2018 Dec 21]; 31:146-57. Available from: https://www.ncbi.nlm.nih.gov/ pubmed/29705447

3. Ministério da Saúde (BR). Portaria № 971 de 03 de maio de 2006 Aprova a Política Nacional de Práticas Integrativas e Complementares (PNPIC) no Sistema Único de Saúde. Brasília (DF): Ministério da Saúde; 2006. [cited 2018 Dec 21]. Available from: http://bvsms.saude.gov.br/ bvs/saudelegis/gm/2006/prt0971_03_05_2006.html

4. Nascimento MC, Barros NF, Nogueira MI, Luz MT. A categoria racionalidade médica e uma nova epistemologia em saúde. Ciênc Saúde Coletiva [Internet]. 2013; [cited 2019 Feb 12]; 18(12):3595-604 Available from: http://www.scielo.br/pdf/csc/v18n12/a16v18n12.pdf

5. Pereira RDM, Alvim NAT. Theoretical and Philosophical aspects of traditional Chinese Medicine: acupuncture, and diagnostic forms their relations with the care of nursing. Rev Enferm UFPE On Line [Internet]. 2013 Jan; [cited 2018 Dec 21]; 7(1):279-88. Available from: https://periodicos.ufpe.br/revistas/revistaenfermagem/article/ download/10231/10824

6. Cechinel A, Fontana SAP, Della KGP, Pereira AS, Prado SS. Estudo/ Análise Documental: uma revisão Teórica e Metodológica. Criar Educ UNESC (Criciúma) [Internet]. 2016 Jan/Jun; [cited 2019 Fev 5]; 5(1):1-7. Available from:http://periodicos.unesc.net/criaredu/article/view/2446

7. Carvalho JLS, Nóbrega MPSS. Complementary therapies as resources for mental health in Primary Health Care. Rev Gaúcha Enferm [Internet]. 2017; [cited 2018 Dec 21]; 38(4):e2017-0014. Available from: http://www.scielo.br/pdf/rgenf/v38n4/en_1983-1447-rgenf-3804-e2017-0014.pdf

8. Lima KMSV, Silva KL, Tesser CD. Integrative and complementary practices and the relation to health promotion: the experience of a municipal healthcare service. Interface (Botucatu) [Internet]. 2014 Jun; [cited 2019 Mar 6]; 18(49):261-72. Available from http://www.scielo.br/scielo.php?script=sci_arttext\&pid=S1414 32832014000200261\&lng=en 
9. Losso LN, Freitas SFT. Avaliação do grau da implantação das práticas integrativas e complementares na Atenção Básica em Santa Catarina, Brasil. Saúde Debate [Internet]. 2017 Sep; [cited 2019 Mar 13 Mar]; 41(3):171-87. Available from: http://www.scielo.br/pdf/sdeb/ v41nspe3/0103-1104-sdeb-41-spe3-0171.pdf

10. Ruela LO, Moura CC, Gradim CVC, Stefanello J, lunes DH, Prado RR. Implementação, acesso e uso das práticas integrativas e complementares no sistema único de saúde: Revisão da literatura. Ciênc Saúde Coletiva [Internet]. 2018; [cited 2018 Sep 26]. Available from: http://www.cienciaesaudecoletiva.com.br/artigos/implementacaoacesso-e-uso-das-praticas-integrativas-e-complementares-nosistema-unico-de-saude-revisao-da-literatura/16793? $\mathrm{id}=16793$

11. Ministério da Saúde (BR). Portaria № 145 de 11 de janeiro de 2017. Altera procedimentos na Tabela de Procedimentos, Medicamentos, Órteses, Próteses e Materiais Especiais do SUS para atendimento na Atenção Básica. Brasília (DF): Ministério da Saúde; 2017 [cited 2018 Dec 21]. Available from: http://bvsms.saude.gov.br/bvs/saudelegis/ sas/2017/prt0145_11_01_2017.html

12. Ministério da Saúde (BR). Portaria № 849 de 27 de março de 2017. Inclui a Arteterapia, Ayurveda, Biodança, Dança Circular, Meditação, Musicoterapia, Naturopatia, Osteopatia, Quiropraxia, Reflexoterapia Reiki, Shantala, Terapia Comunitária Integrativa e Yoga à Política Nacional de Práticas Integrativas e Complementares. Brasília (DF): Ministério da Saúde;2017. [cited 2018 Dec 21]. Available from: http://bvsms.saude.gov. br/bvs/saudelegis/gm/2017/prt0849_28_03_2017.html

13. Ministério da Saúde (BR). Portaria № 702 de 21 março de 2018. Altera a Portaria de Consolidação no 2/GM/MS, de 28 de setembro de 2017, para incluir novas práticas na Política Nacional de Práticas Integrativas e Complementares - PNPIC. Brasília (DF): Ministério da Saúde; 2018. [cited 2018 Dec 21]. Available from: http://bvsms.saude.gov.br/bvs/ saudelegis/gm/2018/prt0702_22_03_2018.html

14. World Health Organization (WHO). WHO traditional medicine strategy: 2014-2023. Geneva:WHO Press; 2013. [cited 2018 Dec 21]. Available from: https://www.who.int/medicines/publications/traditional/ trm_strategy14_23/en/

15. Sousa LA, Barros NF. Integrative and Complementary Practices in the Unified Health System: progresses and challenges. Rev Lat Am Enferm [Internet]. 2018; [cited 2018 Sep 26]; 26:e3041. Available from: http:// www.scielo.br/pdf/rlae/v26/pt_0104-1169-rlae-26-e3041.pdf

16. Ministério da Saúde (BR). Conselho Nacional de Saúde. Recomendação № 010, de 11 de agosto de 2011. Brasília (DF): Ministério da Saúde; 2011. [cited 2018 Dec 21]. Available from: http://conselho.saude.gov. br/ultimas_noticias/2012/19_abr_recomendacao_acupuntura.html

17. Ministério da Saúde (BR). Coordenação Nacional de Práticas Integrativas e Complementares em Saúde (CNPICS). Monitoramento dos sistemas de informação da Atenção Básica e da Média e Alta Complexidade. Relatório de uma sistematização dos dados nacionais de prática integrativas e complementares em saúde (PICS) para o $1^{\circ}$ semestre de 2017. Brasília (DF): Ministério da Saúde; 2018. [cited 2018 Dec 21]. Available from: http://www.saude.sc.gov.br/index. php/informacoes-gerais-documentos/atencao-basica/pics/14504monitoramento-ab-e-mac-1-semestre-de-2017-final/file

18. World Health Organization (WHO). Acupuncture: review and analysis of reports on controlled clinical trials. Geneva:WHO;2003. [cited 2018 Dec 21]. Available from:http://digicollection.org/hss/en/d/Js4926e/

19. Kurebayashi LFS, Freitas GF, Oguisso T. Nurses' perception about diseases that are treated by acupuncture. Rev Esc Enferm USP [Internet]. 2009; [cited 2018 Dec 21]; 43(4):930-6. Available from: http:// www.scielo.br/pdf/reeusp/v43n4/en_a27v43n4.pdf

20. Pimenta FR, Leão LSNO, Pimenta FC. Controle de infecção: um requisito essencial na prática da acupuntura - revisão de literatura. Rev Eletr Enferm [Internet]. 2008; [cited 2019 Mar 13]; 10(3):766-74. Available from: https://www.fen.ufg.br/revista/v10/n3/pdf/v10n3a22.pdf

21. Pereira RDM, Alvim NAT. Acupuncture in care: an integrative review of scientific production of Brazilian nurses. Rev Enferm UFPE On Line [Internet]. 2013 Jul; [cited 2018 Dec 21]; 7(no.esp):4849-59. Available from: https://periodicos.ufpe.br/revistas/revistaenfermagem/article/ view/11743/13998
22. Conselho Federal de Enfermagem (COFEN). Resolução COFEN № 362/2008. Regulamenta no Sistema COFEN/CORENs a atividade de acupuntura e dispõe sobre o registro da especialidade. Brasília (DF): COFEN; 2008. [cited 2018 Dec 21]. Available from: http://www.cofen. gov.br/resoluao-cofen-n-3262008_5414.html

23. Conselho Federal de Enfermagem (COFEN). Resolução COFEN № $581 / 2018$. Atualiza, no âmbito do Sistema Cofen/Conselhos Regionais de Enfermagem, os procedimentos para Registro de Títulos de PósGraduação Lato e Strictu Sensu concedido a Enfermeiros e aprova a lista das especialidades. Brasília (DF): COFEN; 2018. [cited 2018 Dec 21]. Available from: http://www.cofen.gov.br/resolucao-cofenno-581-2018_64383.html

24. Ministério da Saúde (BR). Conselho Nacional de Saúde. Recomendação № 027 de 15 de outubro de 2009. Brasília (DF): Ministério da Saúde; 2009. [cited 2018 Dec 21]. Available from: http://conselho.saude.gov. br/ultimas_noticias/2012/19_abr_recomendacao_acupuntura.html

25. Ministério da Saúde (BR). Conselho Nacional de Saúde. CNS faz recomendação sobre exercício da acupuntura. Brasília (DF): Ministério da Saúde; 2012. [cited 2018 Oct]. Available from: http://conselho. saude.gov.br/ultimas_noticias/2012/19_abr_recomendacao_ acupuntura.html

26. Conselho Federal de Enfermagem (COFEN). Resolução COFEN № 197/1997. Estabelece e reconhece as Terapias Alternativas como especialidade e/ ou qualificação do profissional de Enfermagem. Brasília (DF): COFEN; 1997. [cited 2018 Dec 21]. Available from: http:// www.cofen.gov.br/resoluo-cofen-1971997_4253.html

27. Conselho Federal de Enfermagem (COFEN). Resolução COFEN № 0500/2015. Revoga, expressamente, a Resolução Cofen ํㅜ 197, de 19 de março de 1997, a qual dispõe sobre o estabelecimento e reconhecimento de Terapias Alternativas como especialidade e/ou qualificação do profissional de Enfermagem, e dá outras providências. Brasília (DF): COFEN; 2015. [cited 2018 Dec 21]. Available from: http:// www.cofen.gov.br/resolucao-cofen-no-05002015_36848.html

28. Ministério da Saúde (BR). Embaixada da República Popular da China Nota No 155/2018. Brasília (DF): Ministério da Saúde; 2018 [cited 2018 Dec 21].2 p. Available from: https://www.coffito.gov.br/nsite/wp-content/ uploads/2018/08/nota_embaixada_china.pdf

29. Conselho Federal de Enfermagem (COFEN). Resolução COFEN No $585 / 2018$. Estabelece e reconhece a acupuntura como especialidade e/ou qualificação do profissional de Enfermagem. Brasília (DF) COFEN; 2018. [cited 2018 Dec 21]. Available from: http://www.cofen. gov.br/resolucao-cofen-no-585-2018_64784.html

30. World Acupuncture Day. Under the patronage of the French National Commission for UNESCO. 3 Days of exceptional programs. Paris UNESCO; 2018. [cited 2018 Nov 23]. Available from: https://www. wad-o.com/en/

31. Melo ACC. Nota de esclarecimento. Associação Brasileira de Enfermeiros Acupunturistas e Enfermeiros de Práticas Integrativas; 2018. [cited 27 Sep 2018]. Available from: http://abenanacional.org/ nota-de-esclarecimento/

32. Herdman TH, Kamitsuru S. Diagnósticos de Enfermagem da NANDA-I: definições e classificação 2018-2020/. [NANDA Internacional]. Porto Alegre: Artmed; 2018. 488 p.

33. Conselho Federal de Enfermagem (COFEN). Resolução CFEN № 564/2017. Aprova o novo Código de Ética dos Profissionais de Enfermagem. Brasília (DF): COFEN; 2017. [cited 2018 Dec 21]. Available from: http://www.cofen.gov.br/resolucao-cofenno-5642017_59145.html

34. Conselho Nacional de Educação. Câmara de Educação Superior. Resolução CNE/CES № 3, de 7 de novembro de 2001. Diretrizes Curriculares Nacionais do Curso de Graduação em Enfermagem. Brasília (DF): CNE/CES; 2001. [cited 2018 Dec 21]. Available from: http://portal.mec.gov.br/cne/arquivos/pdf/CES03.pdf

35. Salles LF, Homo RFB, Silva MJP.Práticas integrativas e complementares: situação do seu ensino na graduação de enfermagem no Brasil. Rev Saúde [Internet]. 2014; [cited 2018 Nov 12]; 8(3-4):37-44. Available from: http://revistas.ung.br/index.php/saude/article/view/2005/1579 
36. Savi JL, Saupe R. As terapias alternativas na assistência de enfermagem. Rev Bras Enferm (Brasília) [Internet]. 1995 Oct/Dec; [cited 2018 Nov 12]; 48(4):323-8. Available from: http://www.scielo.br/pdf/ reben/v48n4/v48n4a02.pdf

37. Hall $H$, Leach MJ, Brosnan C, Cant R, Collins M. Registered Nurses communication about patients' use of complementary therapies: A national survey. Patient Educ Couns [Internet]. 2018 Aug; [cited 2018 Dec 21]; 101(8):1403-9. Available from: https://www.ncbi.nlm.nih.gov/ pubmed/29550294

38. Arnon Z, Steinberg D, Attias S, Grimberg O, Peterfreund I, Schiff E, et al. Nurses as boundary actors: Promoting integrative medicine in hospital wards. Complement Ther Clin Pract [Internet]. 2018 May; [cited 2018 Dec 21];31:96-103. Available from: https://www.ncbi.nlm.nih.gov/ pubmed/29705488
39. Ministério da Saúde (BR). Informes da Atenção Básica № 53. Práticas Integrativas e Complementares no SUS: ampliação do acesso. Brasília (DF): Ministério da Saúde; 2009. [cited 2018 Dec 21]. Available from: http://189.28.128.100/dab/docs/publicacoes/informes/psfinfo53.pdf

40. Portaria № 853 de 17 de novembro de 2006. Incluir na Tabela de Serviços/classificações do Sistema de Cadastro Nacional de Estabelecimentos de Saúde - SCNES de Informações do SUS, o serviço de código 068 - Práticas Integrativas e Complementares compondo-o com as seguintes classificações. Brasília (DF): Diário Oficial da União; 2006. [cited 2018 Dec 21]. Available from: http://189.28.128.100/dab/ docs/legislacao/portaria853_17_11_06.pdf 